\title{
Girolamo Cusimano
}

\section{Growing up with trees. Autobiography of a research study*}

\author{
Abstract \\ Cusimano, G.: Growing up with trees. Autobiography of a research study. — Bocc. 28: 37-40. \\ 2019. - ISSN: 1120-4060 printed, 2280-3882 online. \\ Agricultural landscapes and fruit plants unmask, in a backward journey, the subjectivity of the \\ researcher between space, culture and investigative reflection. \\ Key words: cultural geography, rural landscape, memory.
}

\section{The opportunity}

\section{Yesterday}

In June 2018, when my colleague Franco Maria Raimondo invited me to attend the Symposium "Botany at the intersection of Nature, Culture, Art and Science," I asked myself: "Why should I be there?".

The first immediate answer was the friendship that ties me to Franco Maria and our shared engagement to develop research in living territories and communities; and, moreover, the desire to tell about my long relationship with the farming world, its culture and the plants embodying the centuries-old process of harnessing Nature.

I also wanted to bear witness to a collective player who, under Professor Antonino Buttitta's guidance, who passed away a few months ago, had shared with me a huge effort of recording the traditional ergological cultures related to the agricultural world in Sicily.

It was an opportunity to bear witness to each and every colleague, whether mine or not, directly involved like me during the 1970's and 1980's in that challenging investigation work, but also to the farmers, the privileged witnesses who gave me an extraordinary lesson of knowledge and life.

The opportunity, the ancient Greek Kalpós, on which Aristotle dwelled at length in his Rhetoric, was a gift for me, i.e., to communicate and share a story of research and engagement which, I was sure, would have reached deep inside the hearts and minds of the audience, because every single story makes sense only in many people's actions and in

*The text reproposes some parts of a lecture given during a cultural Geography meeting held in Trento in 2000. 
research, a dimension which I believe is a fundamental ethical value.

Today

In the time of the written word, to submit what I had the opportunity to say on that occasion to the more durable memory of paper, I asked myself once again whether Kaıpó $\zeta$, the opportunity, would offer me greater inspiration from having been there. Actually, since then, something changed in the world of the human ties belonging to a community: in Selinunte, on that day of June, Sebastiano Tusa too was present. He also attended, with all his talents, the kaleidoscopic integration of scientific perspectives and intuitions typical of events organized by Franco Maria.

Sebastiano is no longer among us today. He is one of the victims tragically involved in the air disaster happened in Ethiopia on March 10th 2019.

And so, being there back then is today also an emotional opportunity of remembrance and commemoration for a passionate mind who left us suddenly.

But that day, in telling about my experience as a researcher, I mentioned several times the help and the advice I received from Giuseppe "Pino" Aiello who, among the several colleagues and friends I mentioned, companions of a period among the most exciting of the anthropological investigations of those happy years, was for me the most important presence for his deep knowledge of the farming world and for his extraordinary capacity to transform every tool and every motion of agriculture into a drawing. For me, his passing away marks the end of a period, leaving it to history.

\section{Three trees, three worlds.}

\section{The grapevine}

A grapevine initiated me in a mysterious knowledge that had the forbidden taste of nongeographic world. An old farmer told me that the graft is like a baptism, because it tames the rebel nature of the rootstock. The grapevine is similar to humanity: a baptism is needed to redeem its uncontrollable nature. The fast and sure gesture guided by the grafter's experienced hand, which, with a sharp knife, inserts a bud in the living body of the bark and with a blade of ampelodesmos thread makes a perfect suture, repeats, grapevine by grapevine, row by row, year after year. It is the ritual of a sacred gesture at the centre of the myths of every people, the passage from nature to culture, and the action by which humans become stewards of the world. Following the satisfied look of the author of these geometrical shapes of the farming space, much appreciated in literature and art, I learned to recognise disquieting projections of secret desires in it.

At the same time, among the abundant grapevines, full of branches appropriately tied in the upper part to the stake I can all but see the charming sinuous shapes of the 'ladies' who, elegantly along the slopes, motionlessly, go on covering the horizon with their shadows, waves of a dark green sea; the sacred and profane.

\section{The olive tree}

The companion of the time, the olive tree is one the signs that has deeply and permanently marked the Mediterranean landscapes. To me, it was the intermediary to find, within 
the absolute logic of a folk saying, one of the main characters of the sense of human action, the need to deliver the cultural heritage to posterity. A saying goes : "Your grandfather's olive trees, your father's mulberry, your vineyard." Each plant belongs to a human generation, each biological and reproductive rhythm corresponds to a phase of the existence of a community in its process of transferring culture and property. In a universe that we are told to be orderly and unchanging, the olive tree has the task of conveying duration. It is history, together with the family and community, it is the continuity of the present in the past. The tree of peace, it is also the sign of progeny and a gift passed on from generation to generation, steeped in sacredness that becomes a metaphor of human civilization in its highest expression. Memory relies on it. Planting it means defying time, performing an action which is forever, going beyond one's own existence to blend it with that of those who will follow, while testifying to the ultimate gesture of self-sacrifice: the fatigue will help others who will harvest its fruit and message. Saving it means accepting the inheritance of a space made eternal by a promise: fathers and sons.

\section{The lemon}

Called golden apples in the Bible, citrus fruits afford a rich image of Mediterranean agriculture. Outside the metaphor, the development of growing citrus fruits for Italy's Mezzogiorno meant a bet with progress. Nevertheless, talking about citrus fruits involves an approximation forgivable only to those who have a general relationship with the plants or for whom they are numbers to be accounted for: the lemon tree has its own personality. It is the tree of abundance, defying the seasonal aridity of the Mediterranean climate, stimulating the development of a sophisticated technology and of hydraulics. It represented, for some parts of Sicily, the opportunity to make a qualitative leap in the capitalistic sense of agriculture: a myth, a dream perhaps, but full of a propulsive thrust that marked, with its very fast and impetuous spread, some not very large but extremely compact stretches of our coastlines and coastal plains. The landscapes of lemon groves, full of intoxicating scents, take us into a world where technical expertise and commercial ability lived together in a relationship beating disquieting implications, characterising the communities involved with very peculiar and polymorphic social and cultural traits. Losing myself in the labyrinths of the canals that give lifeblood to a plant always in love, I discovered how a community can represent itself through the management and control techniques of its own source of material and cultural reproduction and how the observer's gaze, whether an insider or outsider, can be distant from this world.

\section{Epilogue}

The landscapes and the plants that embody their meaning, over which I thought I could exercise the analytical rigour of the interpretation models, unmasked my bias in the complex relationship with other biases, those of the cultures and of the individuals who made them.

Other trees, keepers of different landscapes, upset my dreams. These are symbolic plants that reorganise the urban spaces around the worship of modern redemption: they are the several Falcone trees in many Sicilian squares, the offshoots of the one growing in Palermo, full of ex-votos and messages, commemorating an exemplary martyr. 


\section{References}

AA.VV. 1983: I mestieri, Circolo Semiologico Siciliano. - Palermo.

— 1986: La ricerca etnoantropologica in Sicilia. $I^{\circ}$ mappa. - Palermo.

Agostaro, G. \& Cusimano, G. 2000: I paesaggi della campagna siciliana. Pp. 359-368 in: Grillotti, M. G., Atlante tematico dell'agricoltura italiana. - Rome.

Aiello, G. \& Cusimano, G. 1988: L'albero della storia. - Pp. 65-74 in: Buttitta, A. (ed.), Le forme del lavoro. - Palermo.

— \& - 1988: L'albero del mito. - Pp. 75-90 in: Buttitta, A. (ed.), Le forme del lavoro. - Palermo. Buttitta, A. (ed.) 1988: Le forme del lavoro. - Palermo.

Cusimano, G. 1980: Viticoltura e vinificazione tradizionali nel palermitano. [in: La cultura materiale in Sicilia.] - Quad. Circolo Semiologico Siciliano 12-13: 311-353.

— 1988: Il ciclo della vite - Pp. 45-64 in: Buttitta, A. (ed.), Le forme del lavoro. - Palermo.

— (ed.) 1989: La mappa delle colture agrarie nella provincia di Palermo, Uomo e Territorio, 4. Palermo.

- 1990: Geografia e cultura materiale. - Palermo.

- 1994: Agrumi, mafia, organizzazione del territorio. - Archivio Storico Sicilia Orientale, 1-3. Catania.

- 1996: La cultura idraulica nel bacino del Mediterraneo. Territorio e irrigazione in Sicilia. Geotema 4: 109-122

— 2001: Gli alberi della (mia) vita. - Pp. 97-103 in: Andreotti, G. \& Salgaro, S. (eds), Geografia culturale, idee ed esperienze. - Trento.

Kinneavy, J. L. \& Eskin, C. R. 2000: Kairos in Aristotle's Rhetoric. - Written Commun. 17(3): 432444.

Address of the author:

Girolamo Cusimano,

University of Palermo, Department of Cultures and Societies, Viale delle Scienze, Bldg. 1590128 Palermo. Italy. E-mail: girolamo.cusimano@unipa.it 